\section{Problems of 'scientific' whaling}

SIR-In a recent Commentary', Fukuzo Nagasaki of Japan's Institute of Cetacean Research defended that country's controversial scientific whaling programme. But the programme has been found to be lacking scientific merit by a substantial proportion of the International Whaling Commission's (IWC) scientific committee.

I shall discuss some fundamental issues of the whaling management problem. Nonetheless, there are some errors in Nagasaki's Commentary. He is mistaken in asserting that IWC adopted the moratorium without consulting its scientific committee. Various forms of moratorium were discussed by IWC virtually every year after a 10-year pause was recommended at the United Nations Conference on the Environment in 1972, until the present form was finally adopted in 1982 . In that period, the question was frequently referred to the scientific committee. The committee never unanimously recommended a moratorium, which is not surprising since it includes scientists involved in the whaling industry. The proposals for a moratorium did not raise purely scientific questions, but the lack of scientific consensus on nearly all management advice was undoubtedly a key factor in IWC's decision in 1982. IWC agreed to review the effects of that decision by 1990 , in part by conducting a "comprehensive assessment" of the status of stocks and management methods.

One of IWC's difficulties is that countries can opt out of its decisions, with the result that the moratorium did not become nominally effective until 1988, 2 years behind schedule. Whaling also continued under a provision allowing countries to issue themselves special permits for scientific research. Japan withdrew its objection to the moratorium in 1988, but joined Iceland and Norway in catching whales under special permit.

Many IWC member countries, aware of past abuses of special permits, were concerned that the moratorium would be undermined. Accordingly, the scientific committee was asked to review research to ensure that it addressed important scientific questions, and that the number of whales killed was not excessive. IWC considered that research should contribute to the future management of whaling, and/or facilitate the comprehensive assessment. Nagasaki fails to mention that IWC, after receiving advice from the scientific committee, adopted resolutions calling on Japan to reconsider its programme because of unresolved scientific controversy about the research, and in the meantime to refrain from catching. Japan has ignored these resolutions.

In the traditional, biological approach to management, attempts were made to predict the yield from a whale stock by applying estimates of demographic parameters such as pregnancy rates, mortality rates and ages at sexual maturity, to mathematical models specifying the yield as a function of the number of whales in a stock. But this approach is not sufficiently powerful to manage whaling because all demographic parameters have to be estimated to levels of precision that cannot be achieved in reality.

The natural mortality rate is one of the key parameters used for predicting yields. But the natural mortality rate in whales seems to vary with age $^{2}$, as it does in many animals, particularly mammals. Unrecognized age-dependence leads to overestimated average population natural mortality, which in turn leads to overoptimistic assessments of yield, and hence to catch limits that risk overexploitation

The main aim of the Japanese research programme is to estimate the agedependent natural mortality schedule (NMS) for minke whales (the smallest of the large whales, and now the only relatively abundant species) in the Southern Ocean. But Nagasaki is wrong in saying that "anti-whalers" insist that the agedependent rates be estimated. The existence of age-dependence in mortality means that previous mortality estimates could not be relied on, because samples from commercial catches contain only older animals. But the conclusion drawn by many of Nagasaki's "anti-whalers" was in fact that effort would be better directed towards finding robust methods of management which will not fail if erroneous values for natural mortality and other biological parameters are used.

The Japanese researchers ignored this conclusion and set out in pursuit of an answer to the wrong question. Their programme entails the collection of age data, for which purpose animals are killed to collect waxy earplugs that have annual growth layers. Although it could be useful to know the NMS, it is not agreed that it is either essential, or that estimates with useful precision can be obtained.

The Japanese researchers first suggested using a time series of population age distributions to estimate the NMS. This is impossible ${ }^{2}$, but this was not conceded until after 2 years of scientific catches had already been taken. What is actually needed is a corresponding time series of rather precise estimates of relative population abundance. Some Japanese researchers seem reluctant to accept analyses showing that these estimates will be cripplingly imprecise because of sampling variability, unless the research were to continue for decades, with total samples of tens of thousands of whales ${ }^{3.4}$. and stock collapse.
If there were no alternative to the traditional approach to management, then refining predictions about the yield by examining specimens could be valuable. But alternative management procedures that do not depend on precise estimates of parameters such as natural mortality are practicable. Various procedures being developed and tested with simulation methods by different groups within IWC's scientific committee perform reasonably well. These alternatives mainly rely on feedback from continual independent monitoring of abundance using sighting surveys, in which whales are counted from ships or aircraft. But the simulations show that the question of population delineation is critical. Whaling is conducted on concentrations of whales, usually on their feeding grounds. Surveys are carried out over much larger areas of ocean, but the whales counted may belong to separate populations, or subpopulations which do not completely mix. Problems arise if catches appropriate for the large area are taken from only a subset of the populations or parts of the area. Satisfactory solutions to these problems are yet to be found.

One of the hopes for the moratorium was that, with whaling in abeyance, a rational discussion could take place on how to overcome deficiencies in whaling management. Instead, scientific whaling has diverted effort into arguing about research programmes which have no prospect of resolving IWC's whaling management problems.

WILLIAM DE LA MARE

Centre for Marine and Ecological Research,

Soerlaan 33 ,

1185 JG Amstelveen, The Netherlands

1. Nagasaki, F. Nature 344, 189 (1990).

2. de la Mare, W.K. Rep. int. Whal. Commn 35, 239-250 (1985).

3. de la Mare, W.K. Rep. int. Whal. Commn 40, 355 (1989). 4. de la Mare, W.K. Rep. int. Whal. Commn (in the press).

\section{Myelinated axon origin}

SIR-In his recent Scientific Correspondence $^{1}$, J. R. Garrett implies that the myelinated axons that I described ${ }^{2}$ in the sympathetic postganglionic nerve following partial denervation of the submandibular gland might not be axons of sympathetic ganglion cells. Because the identity of these processes as axons of superior cervical ganglion cells is fundamental to all of the conclusions in my paper, I would like to respond to Garrett's suggestion.

I presented two pieces of evidence to demonstrate the origin of myelinated axons in the sympathetic postganglionic nerve. First, counting axons in crosssections of the nerve at multiple sites between the superior cervical ganglion and 